\title{
Privately Subsidized Recycling Schemes and their Potential Harm to the Environment of Developing Countries: Does International Trade Law Have a Solution?
}

\author{
Arie Reich*
}

A. Introduction

B. Background: Germany's Recycling Regime

C. Privately Paid, but Governmentally Induced, Subsidies under the SCM Agreement

1. Are they Countervailable?

2. Should they be Countervailable under the SCM Agreement?

3. Harm to the Environment as "Adverse Effect"

D. Can an Importing Country Find Remedy under Article XX of GATT?

E. Summary and Indecisive Conclusions: Textualism or Teleology?

\section{A. Introduction}

The asymmetry in the level of environmental protection between developed and developing countries and its implications for international trade regulation, is an issue that has risen to the limelight of the public debate over the last decade. This in turn has caused an outburst in academic writing around this topic. ${ }^{1}$ On the one hand, there are calls - originating mostly from environmental groups located in the developed world - to use international trade measures in order to enforce higher standards on the developing countries. ${ }^{2}$ In response, developing countries are invoking the asymmetry

\footnotetext{
*Vice Dean and Senior Lecturer, Faculty of Law, Bar Ilan University, Ramat Gan, Israel. E-mail: reicha@mail.biu.ac.il

${ }^{1}$ See for instance, Patrick Low, "Trade and the Environment: What Worries the Developing Countries",23 Environmental Law 705 (1993); Daniel Esty, Greening the GATT: Trade, Environment and the Future (Washington DC: Institute for International Economics, 1994); Scott Vaughan, "Trade and Environment: Some North-South Considerations” 27 Cornell Int'l L. J. 591 (1994); Vinod Rege, "GATT Law and Environment-Related Issues Affecting the Trade of Developing Countries", $28 \mathrm{~J}$. World Trade L. (No. 3) 95 (1994); Jagdish Bhagwati \& T.N. Srinivasan, "Trade and the Environment: Does Environmental Diversity Detract from the Case for Free Trade", in Fair Trade and Harmonization: Prerequisites for Fair Trade? (Bhagwati \& Hudec, eds) (Cambridge: MIT Press, 1996) Vol. 1, Chap. 4.

${ }^{2}$ Some examples of the use of such measure are discussed later in this article, and they include the US embargos on tuna imports and shrimp imports from countries allowing their fleets to employ fishing methods that cause the death of dolphins and turtles, respectively. For an analysis of these measures, see Steve Charnowitz, “A Taxonomy of Environmental Trade Measures”, 6 Georgetown Int'l Env. L. Rev. 1 (1993). This approach was justified by the claim that if higher standards aren't imposed on the developing countries, competitive pressure will force the developed countries to lower theirs. As Walter Russel Mead wrote in a much cited article in Harper's Magazine: "Either the progressive systems of the advanced industrial countries will spread into the developing world or the Third World will move north. Either Mexican wages will move up or American Wages will move down". "Bushism, Found: A Second-Term Agenda Hidden in Trade Agreements”, Harper's Magazine, September 1992, p. 44.
} 
in economic development in order to reject these calls and to justify the differences in environmental protection. "When you went through your industrial revolution", so goes their argument, "there was a complete disregard of the damage caused to the environment. Now, when you have reached a high level of development, with much of your economy relying on the environment-friendly hi-tech and service sectors, and we are going through our industrial revolution, you want to impose on us standards that you yourselves never kept?" Thus, most of the opposition against incorporating environmental norms into the WTO comes from the developing countries, which fear that it will be used in order to bar their exports to developed countries. ${ }^{4}$ Indeed, environmental concerns are quite seldom invoked as a reason to bar exports going the other way - from the rich to the poorer countries. ${ }^{5}$

The issue discussed in this article involves exports going that other way. It relates to products manufactured not only under the perhaps highest possible environmental standards, but also as part of programs created and designed in order to save the environment and promote sustainable development. Nevertheless, these very programs, and these very products, may in certain circumstances actually harm the environment of developing countries, as a result of the asymmetry in economic development and environmental protection between them and the developed countries where the products originate. This may happen, for instance, when such products are exported to developing countries and have a negative impact on the economic viability of collection and recycling of their own waste. Newly established and still struggling recycling plants, unsupported by private or governmental subsidies or other protective measures prevailing in the rich and more environmentally conscious

\footnotetext{
${ }^{3}$ See Low, supra note 1, at 706-707; and Bhagwati \& Srinivasan, ibid., at 168 . The need for special consideration of the asymmetry in economic development of WTO Members is a permanent component of all official resolutions and instruments of the WTO in the field of trade and environment. See for instance, "Decision on Trade and Environment", adopted by ministers at the meeting of the Uruguay Round Trade Negotiations Committee in Marrakesh on 14 April 1994, Results of the Uruguay Round of Multilateral Trade Negotiations: The Legal Texts (Geneva, 1995) 469, $2^{\text {nd }}$ preamble

("seeking both to protect and preserve the environment...in a manner consistent with their respective needs and concerns at different levels of development"). See also the Doha Ministerial Declaration, of 14 November 2001, para. 32, available at:

http://www.wto.org/english/thewto_e/minist_e/min01_e/mindecl_e.htm\#tradeenvironment. In the Rio Declaration of the 1992 United Nations Conference on Environment and Development (UNCED), (reprinted in 31 I.L.M. 874) it was also recognized that trade-environment issues cannot move forward in isolation of wider development commitments, such as technology transfer and financing from the developed to the developing countries.

${ }^{4}$ This is evident from the positions of the developing countries in GATT/WTO negotiations. For example, at the GATT Marrakech Ministerial Meeting in April 1994, the Minister of the Environment of Malaysia, Rafidah Aziz, stated that environmental issues "are now clearly being used to promote protectionist motives, particularly to keep out imports from countries which have a better competitive edge and comparative advantage" (quoted in Vaughan, supra note 1, at 593).

${ }^{5}$ One significant exception is the issue of trade in waste or hazardous substances, where various international treaties seek to restrict the possibility of exporting such substances from developed countries, with high standards of environmental protection, to developing countries, with low standards, in order to prevent the latter from becoming the garbage heap of their richer neighbors. For instance, the Basel Convention on the Control of Transboundary Movement of Hazardous Wastes and their Disposal (1992). That, however, is a much less controversial issue, and the restrictions are not likely to create any significant job-losses in the developed countries. In this article we will be discussing mainly export of real products, manufactured by workers in the developed countries under the highest possible environmental standards, and nevertheless causing harm to the environment of developing countries.
} 
countries, may be forced to close down. Alternatively, they may decide to abandon expensive collection of local waste, in favor of free or subsidized waste imported from developed countries. In both cases, collection and recycling activities in the importing countries are reduced, and sometimes eliminated. As a result, developing countries get stuck with their own waste, which at best piles up in their landfills and at worst is dumped in nature.

The objective of this article is to document and draw attention to this problem and to examine the question of what remedies, if any, may be offered under international trade law (in particular GATT/WTO rules) to affected countries. Would countries in situations as those described above be permitted to take measures against imports harming their recycling activities? Of particular interest in this regard, is how to relate to privately paid, but governmentally induced, subsidies under the WTO Subsidies Agreement? Such subsidies, while fulfilling most economic definitions of subsidies, appear to have escaped the attention of the Agreement's drafters and may therefore be outside its scope. Importing member countries would therefore be precluded from taking countervailing measures against products enjoying such subsidies. These and other potential protective measures will be discussed below, in light of recent case law of the WTO, in particular in the matter of United States Measures Treating Export Restraints as Subsidies. ${ }^{6}$ This discussion will demonstrate the formalistic nature of the existing WTO jurisprudence and show how a more purposive, teleological approach to interpretation of international trade rules could lead to a better solution to the problem at hand.

\section{B. Background: Germany's Recycling Regime}

Germany is a pioneer in the field of state recycling laws. In 1991, it passed the Verpackungsverordnung (Packaging Ordinance), a secondary legislation made under the authority of the 1986 Abfallgesetz (Waste Act). ${ }^{7}$ The Ordinance addresses all types of packaging ${ }^{8}$ and places the basic responsibility for the recycling or reuse of packaging material on the manufacturers. By January 1993, industry had a choice: either a take-back of all primary packaging by the retailers and high mandatory deposits on all non-refillable containers (for beverages, cleaning materials and emulsion paints), or exemption from these requirements provided industry set up a system to recover certain percentages of primary packaging by certain dates. Under pressure of the retailers, who would not agree to the first option, the manufacturers agreed to voluntarily set up a company called Duales System Deutschland AG (DSD) to handle collection and recycling of sales packaging on behalf of the industry. Under the system, manufacturers selling or importing packaged products must pay a fee to DSD to pay for the collection, sorting and recycling of the packaging they are using. This entitles them to put the "Green Dot" symbol on their package. The DSD neither

\footnotetext{
${ }^{6}$ Infra, note 26.

${ }^{7}$ M. Raymond \& D. Perchard, Getting Green Dotted: The German Recycling Law Explained in Plain English (Raymond Communications, 1994).

${ }^{8}$ The Ordinance addresses three types of packaging: 1 . Transport packaging; 2 . Secondary packaging (boxes used for marketing, some blisters, anti-theft, etc.); 3. Primary packaging. By December 1991, distributors or manufacturers had to take back all transport packaging or arrange for its recycling or reuse. As of April1992, retailers had to install containers so consumers cold leave behind secondary packaging. On primary packaging, see in text.
} 
owns nor runs any sorting and recycling plants itself. These functions are contracted out to hundreds of plants, both within Germany and outside. In many sectors, the DSD was forced not only to finance the collection, transportation and sorting of the waste, but also to subsidize the recycling plants. While the plants often receive the lion's share of their income from selling the recycled material in the market, in some instances they demanded and received subsidies from the DSD in order to make it worth their while. ${ }^{9}$

The German consumers responded with an unexpected zeal to participate in the recycling project, and in practice the amounts collected and recycled exceeded the statutory targets by significant amounts. ${ }^{10}$ However, the huge amounts of paper and plastics recycled could not be absorbed by end-use markets within Germany, and so the surpluses had to be exported. Thus, foreign markets were suddenly flooded by these products, putting domestic recycling plants in these countries, which do not enjoy subsidization of their activities, in disadvantage in relation to the cheap German exports. According to press reports, several paper companies in England have gone bankrupt because they cannot compete with the subsidized recycled paper coming from Germany. ${ }^{11}$ British paper companies are reported to have demanded a 60 million-pound subsidy from their government, as part of a voluntary agreement to save them from closure. However, while the problem within the European Community was soon solved by mutual agreement between the Member Countries, and the issuing of a directive by the EC Council and Parliament, aimed at harmonizing recycling schemes among the member Countries, ${ }^{12}$ the problem for third countries still remain. Hence, significant amounts of recycled plastics, paper and corrugated carton are exported at cheap prices to developing countries in the Middle East and Asia. ${ }^{13}$ Injured recycling plants in those countries are highly unlikely to receive subsidies from their governments, nor to enjoy the benefits of a mandated recycling scheme, such as that of Germany. Instead, their more probable response would be to abandon expensive collection and sorting of local waste, and to try to

\footnotetext{
${ }^{9}$ E. Johnson, "Making Plastics Recycling Pay", European Chemical News 22-28 January 1996, p. 18: "For plastic packaging, the DSD - through its subsidiary Deutche Kunststoff Recycling (DKR) - pays extra to cover the cost of recycling. Last year it paid DM 330m for 460,000 tonne of recyclate produced, i.e. an average of DM 720/tonne. The DKR also manages the movement of waste from sorting plants through the rest of the recycling loop." On the DKR's website, these payments are even referred to as "recycling subsidies". See http://www.dkr.de/1026.html

${ }^{10}$ Raymond, supra note 7, page 3. In 1994, instead of collecting $30 \%$, the plastic industry was recycling closer to $80 \%$. This tendency has continued most of the time since then. In the year 2000 , more than $93 \%$ of the plastic packaging was recycled. See information on the official website of the DSD's subsidiary in charge of recycling in the plastic industry, Deutsche Gesellschaft für KunststoffRecycling mbh (DKR): http://www.dkr.de/860.html (visited May 16, 2001). For information on the targets exceeded in other sectors, see the website of DSD: http://www.gruener-punkt.de/en.

${ }^{11}$ Raymond, supra note 7, pages 4-5.

${ }^{12}$ Directive 94/62/EC of the European Parliament and of the Council of 20 December 1994, Official Journal No L 365/10 (31/12/94). This directive is based on Article 100a of the EC Treaty, aims to harmonize national measures concerning the management of packaging and packaging waste. The objective of the directive is not only pure environmental, but also "to ensure the functioning of the internal market and to avoid obstacles to trade as well as distortions and restrictions of competition within the Community" (emphasis added). This objective surely echoes the problems described in the text and the intra-Community tension that followed from them. Article 6(1) of the directive lays down, inter alia, quantified targets to be achieved by Member States for recovery and of packaging waste. Article 6(1)(a) establishes that, no later than 30 June 2001, between $50 \%$ as a minimum and $65 \%$ as a maximum by weight of the packaging waste will be recovered.

${ }^{13}$ Raymond, supra note 7 , page 9.
} 
obtain a contract from the DSD to recycle German waste, and in some cases to even receive subsidies from the DSD in order to perform this task.

The case of the plastic recycling sector in Israel can serve as a good example. Amnir Recycling Industries Ltd. was the pioneer in Israel in the field of recycling and the leading firm involved in the recycling of paper and plastic. Until the cheap imports from Germany started, the company was manufacturing about $80 \%$ of the recycled plastic (mainly polyethylene) consumed in Israel. ${ }^{14}$ The plastic waste that served as its raw material was collected from industrial plants around the country and from farmers who used it for greenhouses. After manufacturing, the recycled polyethylene was sold to the local industry to be used in the manufacture of pipes and plastic bags. When the influx of cheap imports from Germany started in 1996, Amnir was forced to lower its prices and to sell sometimes under cost. The firm nevertheless experienced a sharp decline in its sales, and it was consequently forced to reduce its collection activities (and to lay off some of the collection staff) as well as its production (recycling).

The firm turned to the Ministry of Industry and Trade, to the unit in charge of anti-dumping and anti-subsidy investigations, complaining that the polyethylene from Germany is in fact subsidized and therefore amounts to unfair trade. After consulting its legal advisor, the Ministry responded that it is unable to commence investigations for suspected subsidized imports, due to the fact that the payments allegedly received by the German manufacturer from the DKR (a subsidiary of DSD) do not amount to "subsidies" under the WTO Agreement on Subsidies and Countervailing Measures (the "SCM Agreement"). ${ }^{15}$ After reviewing the facts, the Ministry suggested that the firm consider the possibility of filing an anti-dumping complaint instead. Such a complaint was indeed filed and investigations were commenced. The Ministry even imposed provisional anti-dumping duties, based on prima facie evidence of dumping - i.e., sales at export prices that are lower than the normal price in Germany (price discrimination). However, the final instance, the Trade Levies Committee, reached the conclusion that there was no clear evidence of significant dumping, and that the dumping margin fell below the de minimis threshold. It did however find signs of material injury to Amnir as a result of the imports. In summing up its conclusions, the Committee stated as follows: ${ }^{16}$

Since it has not been found that the imports from Germany have been sold at dumped prices, one cannot link this injury to dumped

\footnotetext{
${ }^{14}$ The details are taken from the decision of Israel's Trade Levies Committee, the tribunal in charge of Anti-dumping and Countervailing Duties procedures, in the complaint of Amnir regarding Dumped Imports of Recycled Polyethylene from Germany, Decision No. 3 in Collection of Decisions of Advisory Committee for Anti-Dumping and Countervailing Duties 1998-2001 (Ministry of Industry and Trade, Trade Levies Unit) (in Hebrew) 77. The author served at the time as the Chairman of the Committee. The decision, as well as all other decisions of the Committee (in Hebrew), can be downloaded from the website of the Ministry of Industry and Trade:

http://www.moit.gov.il/dumping.htm. For a discussion in English of Israel's Anti-dumping and Countervailing Duties procedures, see Arie Reich, "Institutional and Substantive Reform of the Antidumping and Subsidy Agreements: Lessons from the Israeli Experience", 37 Journal of World Trade (Vol. 6) 1037 (2003).

${ }^{15}$ Agreement on Subsidies and Countervailing Measures, reprinted in The Results of the Uruguay Round, supra note 3, at 264. The definition of "subsidy" is found in Article 1 of the Agreement, and will be discussed further in section $\mathrm{C}$ below.

${ }^{16}$ Amnir Decision, supra note 14, page 111 (the author's translation).
} 
imports. Indeed, according to the picture that has emerged before us, the massive influx of polyethylene from Germany originates not from sales at dumped prices, but from the fact that in Germany large surpluses of recycled polyethylene have accumulated that are seeking markets in foreign countries, and that this material can be sold to these countries (despite the high transportation costs) as a result of the generous support of the DKR company to the German manufacturer. This support is manifested, as we have seen, in two components: the provision of free raw material (without the need to bear expenses in connection with collection and sorting of the plastic containers); and significant support payments.

The reason that these increased imports perhaps ought to turn on a warning light lies in their environmental impact. If indeed, they bring about a reduction in the local production of recycled polyethylene - as indicated by our findings - then it must also cause a reduction in the collection and recycling of plastic waste after industrial or agricultural use. If this waste is not collected and recycled, then it is bound to be disposed at best at the landfills, or at worse, in nature. Of course, the imports from Germany do not cause any reduction in the recycling of post consumer plastic waste, due to the simple reason that in Israel there is still no organized collection and recycling of such waste. ${ }^{17}$ However, if in the future such recycling would be contemplated, it is definitely possible that the cheap imports from Germany may prevent such recycling or may make it economically unfeasible. But as mentioned, the imports do appear to be the cause of the reduction in recycling of industrial and agricultural plastic waste. However, the solution to this problem is not in the hands of this Committee, and the remedy to these injuries, if indeed they are caused, is not anti-dumping duties. It would seem to us that the Ministry of Environment ought to put its mind to this problem, and the sooner the better.

In practice, the Ministry of Environment, while recognizing the problem and the detrimental effect the imports from Germany could have on the Israeli environment, especially in light of the serious situation of the country's landfills, considered itself unable to prevent the imports or to provide any other assistance to the recycling industry.

\section{Privately Paid, but Governmentally Induced, Subsidies under the SCM Agreement}

\section{Are they Countervailable?}

\footnotetext{
${ }^{17}$ In the meanwhile, after the decision was given, Israel has taken legislative measures in order to encourage recycling of consumer plastic waste. In April 1999, the Deposit Law on Beverage Containers was adopted by the Knesset, and it came into force on October 1, 2001. These measures are still far from reaching satisfactory levels of recycling. Containers over 1.5 liters, which are most common, are still not covered by the Law. At most, the Law targets $60 \%$ of all the beverage containers, and they only make up about $4 \%$ of total municipal waste and $8 \%$ of the volume (Figures taken from the website of Israel's Ministry of the Environment: http://www.sviva.gov.il, visited 2.9.04)).
} 
On the face of it, the story of the German polyethylene exports sounds like a classic case of countervailable subsidies. A German manufacturer receives financial support from some national body established to promote a specific manufacturing sector in the name of some national policy objectives. Consequently, the manufactured products are exported at cheap prices to foreign countries, thus inflicting material injury on domestic manufacturers of like products. Under well-established international trade law, the domestic industry has the right to submit a complaint against the subsidized imports, and to apply for a remedy in the form of countervailing duties imposed on the imports, and set at an amount equivalent to the amount of the subsidy, or less. This type of remedy was recognized as legitimate already in the 1947 General Agreement on Tariffs and Trade (GATT), ${ }^{18}$ and is now regulated by the WTO SCM Agreement. ${ }^{19}$ Why then was Amnir advised that such a complaint was impossible?

\section{“A Financial Contribution by a Government or any Public Body"}

The answer lies in the definition of the term "Subsidy" found in Article 1 of the SCM Agreement. According to this definition, a subsidy is deemed to exist if "there is a financial contribution by a government or any public body within the territory of a Member ... and a benefit is thereby conferred" (emphasis added). ${ }^{20} \mathrm{~A}$ critical component of the definition is thus that the financial contribution to the manufacturer comes from a government or from a public body. The payments received by the German manufacturers of recycled polyethylene do not seem to fulfill this requirement. The DKR, who pays out the subsidies, is not a governmental agency, nor could it be considered to be a public body. It is a privately owned company, whose shareholders are the DSD and an amalgamation of German-based companies and associations from the plastics producing and processing industry and plastic machine manufacturers. ${ }^{21}$ The DSD is also privately owned by some 600 shareholders from the industry and trade. ${ }^{22}$ Thus, while all the other components of the definition would seem to be fulfilled in this case ("a financial contribution" in the form of "a direct transfer of funds", and "a benefit is thereby conferred"), the component relating to the identity of the contributor is not fulfilled. In other words, even though the DKR itself refers to its payments as "recycling subsidies", ${ }^{23}$ these payments do not seem to fall into the definition of the Subsidies Agreement.

\section{(b) The "Private Body" Provision}

Albeit, the definition allows for a certain amount of latitude in this regard, by the addition in subsection (a)(1)(iv) of the following provision:

\footnotetext{
${ }^{18}$ See Article VI:3 and VI:6 of the General Agreement of Tariffs and Trade, opened for signature on October 30, 1947, 55 U.N.T.S. 194; T.I.A.S. No. 1700 [hereinafter GATT].

${ }^{19}$ Supra note 15

${ }^{20}$ Article 1:1(a)(1) of the SCM Agreement, supra note 15.

${ }^{21}$ Based on information from the DKR's website: http://www.dkr.de/864.html (visited on May 19, 2001).

${ }^{22}$ Based on information from the DSS's website: http://www.gruenerpunkt.de/en/index.php3?choice1=ds\&choice2=philosophie (visited on May 19, 2001).

${ }^{23}$ See http://www.dkr.de/1026.html.
} 
"a government makes payments to a funding mechanism, or entrusts or directs a private body to carry out one or more of the functions illustrated in (i) to (iii) above which would normally be vested in the government and the practice, in no real sense, differs from practices normally followed by governments."

This addition would seem to aim at a situation similar to our case, where the payment is fulfilling all of the essential characteristics of a subsidy - a financial contribution in one of the forms illustrated in subsections (i) to (iii), which confers a benefit to the recipient - but which is made not by the government or a public body, as required in the chapeau of the provision, but by a private body.

However, the language is quite restrictive. It requires that the private body in such case has been directed or entrusted to carry out the financial contribution. It also requires that this function is one which would normally be vested in the government, and that the practice [i.e., the carrying out of the said functions] in no real sense differs from practices normally followed by governments. What is the meaning of these requirements? Can they be said to have been fulfilled in our case?

The answer to these questions depends on the interpretative approach taken in relation to this provision. A strict, textual (and perhaps formalistic) approach would require us to look for an actual and express direction or entrustment by the government to the private body to carry out one or more of the functions illustrated in paragraphs (i)-(iii) of Article 1.1(a)(1). A less strict approach would be willing to consider somewhat less explicit and direct means used by governments to induce private bodies to carry out the said functions. Such an approach could be based on a broad understanding of the term "directs", as including any act that regulates the behavior of the private body or causes it to move on a particular course. It could also be based on a purposive, teleological interpretation of the provision, which looks at its rationale and purpose, and asks itself whether the measure in question falls within this rationale. Thus, one may argue that the purpose of sub-paragraph (iv) is to prevent the circumvention of paragraphs (i) to (iii) by a government, simply by acting through a private body. It should therefore be understood to include any such act, whether it is an express direction or entrustment, or anything else that is functionally equivalent to such a direction or entrustment.

WTO panels, as well as the Appellate Body, usually prefer the more strict and formalistic approach to interpretation, so as not to be accused of "judicial legislation" or violation of Article 19.2 of the Dispute Settlement Understanding. ${ }^{24}$ For this and other reasons, they are therefore more likely to choose the former interpretation. ${ }^{25}$

\footnotetext{
${ }^{24}$ The Understanding on Rules and Procedures Governing the Settlement of Disputes (DSU), Annex 2 of the Agreement Establishing the World Trade Organization, reprinted in The Results of the Uruguay Round of Multilateral Trade Negotiations: The Legal Texts (Geneva, 1995) 404. Article 19.2 of the DSU provides that "in their findings and recommendations, the panel and Appellate Body cannot add to or diminish the rights provided in the covered agreements."

${ }^{25}$ On June 5, 2001, the author presented this paper for the first time, in an international conference hosted by the Hebrew University in Jerusalem, and predicted that WTO panels would choose the more formalistic interpretation and require the finding of an actual and express direction by the government to the private body. While this prediction was disputed by some of the participants in the conference, who thought that a more functional approach could be adopted, it was confirmed only three weeks
} 


\section{(c) The Panel Report on Measures Treating Export Restraints as Subsidies}

Indeed, that is precisely what a recent WTO panel, in the matter of United States - Measures Treating Export Restraints as Subsidies ${ }^{26}$ - charged with the task of interpreting paragraph (iv), did. The dispute before the panel concerned the U.S. position that in some circumstances export restraints can be treated as subsidies and therefore be countervailed. This will happen in a situation where an export restraint forces the domestic producers of the restrained products to sell at depressed prices to domestic down-the-stream manufacturers, which consequently will enjoy input at less than world-market prices. The U.S. claimed that such measures constitute a financial contribution to these manufacturers in the form of government-entrusted or government-directed provision of goods in the sense of Article 1.1(a)(iii) and (iv) of the SCM Agreement. The view of the U.S. was that a government limitation or outright prohibition of exports of the product in question is different only semantically from an affirmative direction to a private entity to provide goods (to a greater degree than before or exclusively) to domestic producers. ${ }^{27}$ The panel rejected the U.S. assertion that one should look at things "non-semantically" and include in Article 1.1(a)(iv) acts that are "functionally equivalent" to an entrustment of or direction to a private body. The panel ruled:

"It follows from the ordinary meaning of the words "entrust" and "direct" that the action of the government must contain a notion of delegation (in the case of entrustment) or command (in the case of direction). To our minds, both the act of entrusting and that of directing therefore necessarily carry with them the following three elements: (i) an explicit and affirmative action, be it delegation or command; (ii) addressed to a particular party; and (iii) the object of which action is a particular task or duty.... We therefore do not believe that either entrustment or direction could be said to have occurred until all of these three elements are present." 28

\section{(d) A Government "entrusts or directs"}

Based on this rendering of Article 1.1(a)(iv), it is quite clear that the payments made by DKR to the recycling plants do not qualify as "subsidies" under the SCM Agreement. One can hardly claim the DKR to have been directed or entrusted by the German government to make the subsidy payments. There was no delegation, nor any command to make such payment. The DKR was never the recipient of any such direction or entrustment. Even the manufacturers who established the DKR were

\footnotetext{
later, when the Panel decision on United States - Measures Treating Export Restraints as Subsidies, infra note 26, was published.

${ }^{26}$ United States - Measures Treating Export Restraints as Subsidies - "Complaint by Canada", (WT/DS194/R). The Panel Report was adopted by the Dispute Settlement Body on 23 August 2001. It has not been appealed.

${ }^{27}$ Ibid., para. 8.22

${ }^{28}$ Ibid., para. 8.29.
} 
never directed, strictly speaking, to carry out any of those functions. They were given a choice, by the German legislator to choose between two options, one of which was to set up a system to recycle certain percentages of primary packaging by certain dates. For economic reasons they chose this option, and in order to perform it and to escape fines that would be imposed on them if they failed to live up to its requirements, they established the DKR, who in turn chose to pay the recycling plants certain amounts of money. The sums that were paid were determined by the DKR, and not by the government, and they were paid in order to make it economically viable for the recycling plants to accept the task.

But what about the collection and supply of raw-material (the used packaging) to the recycling plants? Could that be considered as provision of "goods or services other than general infrastructure" under subparagraph (iii), which a private body (the DKR) has been directed by the government to carry out?

Based on the strict approach of the Export Restraints panel, one could argue that this situation is still not fulfilling the requirement of "an explicit and affirmative action of delegation or command", 29 because it is not the provision of goods or services to the recycling plants that the DKR or the manufacturers were commanded to do. They were commanded to collect and to recycle, and this they could do in any way they find fit. In the Export Restraints case, the panel stressed that the phrase "type of functions", used in subparagraph (iv), refers to the physical functions identified in subparagraphs (i)-(iii), and that therefore the scope of the actions covered by these provisions must be the same. ${ }^{30}$ The panel made this point in order to reject the U.S. argument that the word "type" used in the provision suggests that "functions of the general form, structure or character as those illustrated in subparagraphs (i)-(iii) would likewise constitute the indirect provision of a financial contribution." Consequently, the private body must have been explicitly and affirmatively commanded to "provide goods or services" to the producer in question. Anything else, even though effectively similar to that, will not suffice.

On the other hand, under a more functional approach, one could argue that there has in fact been such a commandment. The German legislator in effect commanded the manufacturers to choose between two options, one of which was to collect and recycle certain amounts of plastic packaging. Once they chose that option, they were under a continuous obligation to fulfill that commandment. In that sense, they were in a situation different from that of the restrained input producers in the Export Restraints case. The latter were under no obligation to provide their products to anyone. They could choose not to produce them or to produce them and not to sell them. The German manufacturers did not have that choice. They had to collect and they had to recycle. Since these manufacturers are not recycling plants and do not have the tools or expertise required in order to engage in recycling, they had no choice but to provide the collected material to recycling plants. If this provision of goods by the DKR on behalf of the manufacturers, could be shown to confer a benefit on the recycling plants in relation to the market, ${ }^{31}$ by virtue of the fact that the goods are

\footnotetext{
${ }^{29}$ The Export Restraints Report, supra note 26, para. 8.44.

${ }^{30}$ Ibid., para. 8.53.

${ }^{31}$ See Article 14 of the SCM Agreement, supra note 15
} 
provided to them for free, and without having to incur collection and sorting costs, ${ }^{32}$ then it could arguably qualify as a subsidy, even according to the Export Restraints decision.

(e) "Which would normally be vested in the government", and "the practice, in no real sense differs from practices normally followed by governments"

The Export Restraints panel did not really go into the question of how to interpret the last two elements of subparagraph (iv) quoted above. While both the U.S. and Canada submitted arguments in this regard - the U.S. arguing that these elements in effect broaden the scope of the provision, and Canada arguing the opposite - the panel did not consider it necessary to make any finding in this regard. ${ }^{33}$ It only expressed its "serious doubts" regarding both of the parties' arguments in this matter. Here, then, we cannot rely on the panel for any guidance as to the meaning of these two elements.

It appears that the language in this regard (at least of the second element) originated in the 1960 report of the Panel on Review Pursuant to Article XVI:5. ${ }^{34}$ This report discussed the question of whether subsidies financed by a non-governmental levy had to be notified under the GATT Article XVI provisions on subsidies. The panel noted that in general there was no obligation to notify schemes in which a group of producers voluntarily taxed themselves in order to subsidize exports of a product. On the other hand, the panel had no doubt that there was an obligation to notify all schemes of levy/subsidy affecting imports or exports in which the government took a part "either by making payments into a common fund or entrusting to a private body the functions of taxation and subsidization with the result that the practice would in no real sense differ from those normally followed by governments." "F5 From the context, it would seem that by using this language, the panel was trying to draw a clear distinction between private and governmental practices. The point it was making was that if certain functions of taxation and subsidization are practiced in a way that they in no real sense differ from those normally followed by governments, then the fact that the government has entrusted these functions to a private body should not make any difference. In other words, the government cannot avoid otherwise applicable subsidy disciplines only by using a private sector surrogate to make the financial contributions that the government normally would have made directly. The meaning of the "normally followed by government" requirement is thus to require an examination of the nature of the practice in order to determine if it is essentially ("in no real sense...") similar to governmental practices, in which case it will be considered as such.

The same applies in principle to this language as it was adopted into Article 1.1(a)(1)(iv) of the SCM Agreement. One needs to examine the nature of the function

\footnotetext{
${ }^{32}$ Under the German system, the DSD contracts and pays private waste management firms to take care of the collection and sorting of the used plastic packaging and to supply it to the recycling plants employed by the DKR.

${ }^{33}$ Ibid., para. 8.59.

${ }^{34}$ Review Pursuant to Article XVI:5, Report of the Panel, L/1160, adopted 24 May 1960 (BISD 9S/188).

${ }^{35}$ Ibid., para. 12.
} 
carried out by the private body, in order to determine whether it fulfills the two specified requirements, which would indicate its "governmental" qualities. It is not enough that the private body has been directed or entrusted by the government to fulfill any of the functions in question; otherwise the use of this language would be redundant. Apparently, the drafters of the provision wanted to make sure that the definition of subsidies would apply only where the financial contribution or provision of goods or services by the private body was genuinely governmental in its nature. To that effect, they directed us to examine two parameters: the nature of the function itself (whether it is one that is normally vested in the government), and the manner in which the practice is carried out by the private entity (whether it in no real sense differs from practices normally followed by governments).

Turning to the first of these parameters, one could ask oneself when is a function one that is "normally" vested in the government? Is this a factual question determined according to whether most of the governments around the world are vested with that function? If so, it would seem to require factual evidence on the practice among the majority of governments in this regard, to be brought before the panel in case of a dispute. Or perhaps it is determined in relation to some commonly accepted standard of what functions are normally vested with governments. ${ }^{36}$ The latter approach raises other problems, such as whether such a standard exists? How would one establish it? And whether it isn't an issue that is dependent on political culture and ideology? The proper scope of government intervention in the economy is of course an issue that is widely disputed among different states and different political theories.

These problems become quite apparent when we try to apply this parameter on the German recycling case. Can one regard the DKR as performing a function "which would normally be vested in the government"? Whether the function in question is the financial contribution to private firms, so that they will agree to take care of recycling, or whether it is the provision of collected and sorted plastic waste for free to these firms - it is indeed a function that in some countries (in particular in the West) is vested in the government. However, in several others it is a function performed by private firms, and in yet more countries (in particular most of the developing countries, where recycling is almost non-existent) it is not vested with anyone. So in terms of the factual approach to this requirement, if it is understood to refer to the practice among most of the governments in the world, it is doubtful that the German case meets the requirement.

If, however, the "standard approach" is adopted, perhaps the outcome will be different. Here one could claim that the fact that some governments lack the economic resources or environmental awareness to take care of collection, sorting and recycling of waste does not mean that the proper standard for government functions doesn't require such involvement, and that the function itself isn't by its nature a government function. If these functions can be shown to be providing a "public good" (in the sense that they are benefiting the entire public and are non-excludable ${ }^{37}$ ), and that

\footnotetext{
${ }^{36}$ Websters New World College Dictionary defines the term "normal" as "conforming with or constituting an accepted standard, model or pattern" ( $3^{\text {rd }}$ ed., 1996) 925.

${ }^{37}$ Meaning that access to them cannot be reserved only for them who pay their cost. The provision of such goods therefore entails the problem of "free riders", which justify the involvement of government.
} 
they are non-profitable and can therefore only be performed by private firms if the government has stepped in and provided proper financial incentives or legal sanctions, then this could be seen as a function that normally, by accepted standard, is vested in the government. Recycling usually fulfills all these criteria.

It is, however, questionable whether a WTO panel would adopt the "standard" approach, due to its potentially controversial nature. It seems more likely that the factual approach, which is more value-neutral, would be adopted. In order to make this approach more helpful, a panel could lighten the burden of proof as to the normal/common usage among governments, and deem it to have been satisfied if at least $a$ significant number of governments have been shown to be vested with the function in question. In such case, perhaps the German case could meet this requirement.

The final obstacle is the last sentence of this provision, which requires that the practice of the DKR, whereby it makes these financial contributions, "in no real sense differs from practices normally followed by governments." Here again, the outcome may depend on the interpretive approach taken.

From the reasoning of the Export Restraints panel, it appears that it understands this requirement to refer to the delegation to private parties not only of the government function of expenditure of revenue (i.e. the "financial contribution"), but also of the collection of revenues (i.e., taxation). ${ }^{38}$ This would seem to mean that for the function fulfilled by the private body to "in no real sense differ from practices normally followed by governments", it would have to include both some type of taxation, as well as the payment of the subsidy. Only this would make the actions of the private body similar to the functions of sovereign governments whereby they collect revenues and expend them. Such a reading would narrow considerably the scope of the private body provision. It also appears to read into it elements that are not included in the provision. Article 1.1 refers only to the "financial contribution" function - whether in the form of direct transfer of funds, foregoing of government revenues or provision of goods or services - and nowhere is there any mentioning of the collection of revenues to finance such contributions. To apply such a requirement

See "Prisoners' Dilemma and the Theory of the State", in The New Palgrave Dictionary of Economics and the Law (London: Macmillan, 1998), 100.

${ }^{38}$ The Panel quotes a paper prepared by the GATT Secretariat at the request of the Negotiating Group on Subsidies and Countervailing Measures during the Uruguay Round leading up to the conclusion of the SCM Agreement. The Panel notes that the inclusion of government transfers effected through nongovernmental agents closely reflects a view expressed prior to the Uruguay Round by a Group of Experts on the Calculation of the Amount of a Subsidy (a body operating under the Tokyo Round Committee on Subsidies and Countervailing Measures), which was quoted in the Secretariat paper. The paper is quoted as follows: "It is suggested that there can be no subsidy in the absence of a financial contribution by government, or in other words that a subsidy presupposes such a contribution. Such an approach would seem to be useful to the extent that it underlines that there is a necessary link between a subsidy and the taxation function of government, exercised either directly or delegated to other, private bodies... There may be similar situations in which a government chooses to direct a private body to carry out certain functions related to the sovereign right of governments to collect revenues and expend them." (para. 8.71 of the Export Restraints Panel Report, supra note 26. The Panel noted that it found very significant the Group of Experts' interpretation that the 1960 Panel's reference to "practice ...in no real sense different from those normally followed by governments" was "a general reference to the delegation to private parties of the particular government functions of taxation and expenditure of revenue, and not a reference to government market interventions in the general sense, or the effects thereof." (Ibid., para. 8.72). 
to the private body provision, when it expressly refers solely to the "type of functions illustrated in (i) to (iii) above", and not to any other governmental functions, would seem to go beyond its ordinary meaning. It would therefore not be in line with the Vienna Convention's demand that a treaty be interpreted "in good faith according with the ordinary meaning to be given to the terms of the treaty..." 39

If nevertheless this interpretation would be employed, it would most probably exclude the German case from the definition of "subsidies". The reason is that unlike governments, the DKR does not impose any mandatory taxes in order to finance its subsidization of certain recycling plants. The source of its finances are better characterized as commercial fees, paid by manufacturers for the right to put the "Green Dot" symbol on their package, and in exchange for collection and recycling services provided on their behalf by the DKR.

A more likely interpretation of the requirement in question is that it deals solely with the financial contribution function performed by the private body, and refers to the manner and the objectives for which it is carried out. In other words, there must be some governmental attributes to the practice in question, so that the fact that it is done by a private entity becomes essentially irrelevant, because the practice in no real sense differs from practices normally followed by governments. One essential feature of government practices is that they are not profit-motivated. Governments decide upon a policy objective, which in their opinion is worthy of subsidization, determine objective standards on how to disburse the subsidies, to whom and how much, and then proceed to act accordingly.

Here one could argue that there are certain "governmental" attributes to the activities of national associations, such as the DKR and the DSD. They have been established pursuant to, or following, legislation aimed to achieve certain national objectives. Their goals are to achieve those objectives, and even though they are nongovernmental bodies, they are usually not profit-motivated, but function as non-profit organizations. They pay their subsidies to recycling plants not in return for any direct consideration from those plants, but in return for the attainment through those plants of those national objectives of waste recycling. The subsidies are probably paid to the various plants according to some predetermined objective standards (for instance, volumes of waste recycled). Based on these arguments, one could therefore credibly argue that the "financial contribution" function carried out by such private bodies "in no real sense differs from practices followed by governments".

\section{(f) Conclusion}

What I have tried to show in my above discussion of Article 1(a)(1)(iv)of the SCM Agreement is that a purposive, teleological interpretation of this provision, which looks at its rationale and purpose, could permit us to consider the payments and free

\footnotetext{
${ }^{39}$ Vienna Convention on the Law of Treaties, 8 I.L.M. 679 (1969), Article 31.1 ("General rule of interpretation"). The WTO Appellate Body has repeatedly ruled that this general rule of interpretation has attained the status of a rule of customary or general international law and as such should guide the WTO panels in the interpretation of WTO agreements. See e.g. United States - Standards for Reformulated and Conventional Gasoline, Report of the Appellate Body, WT/DS2/AB/R, adopted 20 May 1996, p. 16.
} 
services that recycling plants receive under the German recycling scheme (and its likes) as "subsidies" under the SCM Agreement. It is however questionable, in view of the strict and somewhat formalistic interpretative approach reflected generally in WTO panel decisions, whether such an interpretation will in fact be adopted by a WTO panel. Considering in particular the Export Restraints Case, it does not seem likely that panels will be willing to extend the "private body" provision of SCM Agreement Article 1 to include such payments or services. If that is the case, they could not be subject to any countervailing duty investigation or imposition, even if the products manufactured by these plants and imported into another country cause material injury to the importing country's domestic industry and to its environment. ${ }^{40}$

\section{Should they be Countervailable under the SCM Agreement? - A Normative Analysis and Proposed Amendment}

The conclusion of the previous section, according to which a WTO member is probably precluded from using countervailing duties in order to prevent the collapse of its recycling scheme as a result of privately subsidized recycling schemes of other countries, leads us to ask whether this is a desirable situation, or whether the SCM Agreement ought to be amended in this regard. To be more precise, we would like to question the logic and utility of the restrictive language of the SCM Agreement's definition of "subsidies". The discussion will focus on subparagraph (iv) of Article 1.1(a)(1), namely the provision dealing with subsidization by a funding mechanism or private body.

We can derive some guidance in this regard by examining the rationale of countervailing duties, and of the permission given by GATT since its inception in 1947 to use such measures. ${ }^{41}$ A countervailing duty is defined by the SCM Agreement as "a special duty levied for the purpose of offsetting any subsidy bestowed directly or indirectly upon the manufacture, production or export of any merchandise". ${ }^{42}$ Such a duty may be imposed if it is found, after due investigation, that the said merchandise when imported into the imposing country causes material injury, or threat of injury, to its domestic industry. Since the advantage enjoyed by the foreign producer, which allows her to charge less for her merchandise than the domestic industry, is not a result of a genuine comparative advantage, i.e., greater efficiency, but of the subsidies she receives, this represents a distortion of the market mechanism. The domestic producer is therefore seen as justified when he claims that he is unable to compete on such terms, and that global efficiency will not be served by his exit

\footnotetext{
${ }^{40}$ The SCM Agreement makes a clear link between Part V of the Agreement, dealing with Countervailing Duties, and the rest of the Agreement. Thus, Article 10 provides that countervailing duties may only be imposed pursuant to investigations initiated and conducted in accordance with the provisions of the SCM Agreement. Such investigation can only be initiated upon a written application on behalf of the industry that includes sufficient evidence on the existence of "a subsidy" (Article 11.1 and 11.2). Thus, if the subject matter of the application does not meet the definition of the term "subsidy" under Article 1 of the SCM Agreement, a WTO Member Country may not initiate a countervailing duty investigation upon such an application, and is therefore precluded from imposing any countervailing duty on imports receiving such "non-subsidies".

${ }^{41}$ See Article VI:3 of the GATT, supra note 18.

${ }^{42}$ The SCM Agreement, supra note 15, Article 10, footnote 36. This definition is found already in paragraph 3 of Article VI of GATT, supra note 18.
} 
from the market. From this point of view, the question of whether the financial contribution received by the foreign producer originates from a governmental agency, or from a private body that is induced, directly or indirectly, by legislation to make such a contribution, is completely irrelevant. What matters is that the low prices charged by the foreign producer do not represent a genuine efficiency advantage, and do not indicate that the domestic producers have room to improve their efficiency. Under such circumstances, countervailing duties (set at no more than the amount of the subsidy) can be seen as offsetting this artificial advantage and restoring the "level playing field" between the various producers. ${ }^{43}$

Many economists have argued against the rationale of countervailing duties - from the point of view of the imposing country, not from a global perspective - claiming that it is a very unwise response by the importing country. They argue that if a government of a foreign country wishes to subsidize the exports to an importing country, the latter - or at least its consumers - should be grateful for the gift they have received. ${ }^{44}$ This bounty necessarily benefits the consumers more than what it harms the domestic producers, so the country as a whole is better off than in the absence of the subsidy. However, even these critics would be able to justify the imposition of countervailing duties, when what's at stake is the environment of the importing country, and the "material injury" is inflicted not just on the business of the domestic producers, but also on the importing country's ability to collect and recycle its waste. Under such circumstances, the external costs caused by the harm to the environment join with the costs of the domestic industry, and together they outweigh the benefit of the consumers from cheap imports. A countervailing duty, equal to the amount of the subsidy received by the foreign recycling plant (or less, if a lesser duty may suffice ${ }^{45}$ ), would restore the ability of the domestic recycling plant to compete with the imports and thus continue its operation under fair, but competitive, conditions. Provided the duty is set at the proper level, this would seem to be a remedy superior to an outright prohibition on the importation, since it would retain the competitive pressure on the domestic plant, thus insuring its continued efficiency and preventing it from establishing a monopoly.

The rationale behind the permission to act against actionable subsidies would seem to apply to the same extent regardless of whether the subsidies are paid by a governmental agency or by a private body induced to do so by the

\footnotetext{
${ }^{43}$ That the object of the SCM Agreement is to prevent distortions of the market has been recognized by several WTO Panels. See for instance the Panel Report in Brazil - Export Financing Programs for Aircraft (WT/DS/46R) which ruled: "the object and purpose of the SCM Agreement is to impose multilateral disciplines on subsidies which distort international trade."

${ }^{44}$ See e.g., John Jackson, The World Trading System: Law and Policy of International Economic Relations (Cambridge, Mass: The MIT Press, 1989) 251; and Michael J. Trebilcock \& Robert Howse, The Regulation of International Trade (London: Routledge, 1995) 149.

${ }^{45}$ This line of action is in accordance with the "Lesser Duty Rule", used in many countries (e.g., the European Community and Israel) in their anti-dumping and countervailing duties procedures.

According to this rule, which is "recommended" but not mandated under the SCM Agreement, if a duty at a rate that is lower than the full amount of the subsidy (or dumping rate, in anti-dumping proceedings) is sufficient to prevent the material injury to the domestic industry, then the duty should be set at such a rate. See...
} 
government. What matters is the fact that the recipient of the subsidies has been placed in a situation more advantageous than under regular market conditions, and that this has caused material injury to another party.

In the Canada Aircraft case, the WTO Appellate Body confirmed the position of a panel that rejected the "cost to government" test in relation to the definition of subsidies, and instead adopted the market test as the proper benchmark for determining whether a "benefit" has been conferred. ${ }^{46}$ Accordingly, a subsidy is deemed to confer a benefit, under Article 1 of the SCM Agreement, if it is provided on terms that are more advantageous than those that would have been available to the recipient on the market. ${ }^{47}$ In rejecting Canada's position, according to which what matters in the determination of a benefit is the cost to the government that is claimed to have paid subsidies, the Appellate Body notes that such a position would exclude those situations where a "benefit" is conferred by a private body under the direction of a government. ${ }^{48}$ Since such situations are expressly included in the definition of subsidies under Article 1, Canada's position could not be accepted. These decisions are of course based primarily on a textual analysis of Article 1, and relate to the element of "benefit", not to the "financial contribution" element. Therefore, they cannot lead us to a different conclusion than that which we arrived at in the previous section, namely that it is questionable whether the financial contributions made under the German recycling scheme can qualify as "subsidies" under the definition of the SCM Agreement. However, the economic logic that they reflect seem to apply equally regardless of whether the private body that has made the financial contribution to the manufacturer, and thereby conferred a benefit on it, has been expressly directed or entrusted by the government to do so, or whether it has been induced to do so by legislation that leaves it only inferior alternatives. Under the same logic, it would also be irrelevant whether, when making the contribution, this body was performing a function "which would normally be vested in the government" or not. Likewise it would not matter whether the body is following practices that "in no real sense differ from practices normally followed by governments." What does matter is the fact that the body is making financial contributions to manufacturers, which it would not make in the absence of government intervention, and that these manufacturers derive a benefit - in relation to normal market conditions - from these contributions. It is therefore hard to understand why such contributions should not be included in the definition of "subsidies" under the SCM Agreement. It would also seem to open a potential loophole for governments interested in circumventing the provisions of this Agreement.

Take for instance the case of the Government of Urbania who wishes to subsidize manufacturers of, say, semi-conductors, which is a new sector in its economy. Following legal advice, it passes a law that requires the manufacturers of widgets - a strong and well-established industry - to ensure that the annual production of semi-conductors within Urbania will increase

\footnotetext{
${ }^{46}$ Canada-Measures Affecting the Export of Civilian Aircraft, AB-1999-2, WT/DS70/AB/R (2 August 1999), para. .

${ }^{47}$ Ibid., para. 149.

${ }^{48}$ Ibid., para. 160.
} 
steadily by $20 \%$ each year over a period of the next five years. Failure to reach the required targets will result in fines. In order to comply with the new law, the Urbania Association of Widget Manufacturers (UAWM) enters into contracts with newly established manufacturers of semi-conductors, wherein the former undertakes to make financial contributions to the latter in order to help them to establish their production facilities, increase their production and exports, and meet the statutory targets. Since the widget sector is a strong and wellestablished sector (and perhaps also enjoys natural or artificial protection from imports), it is able to finance these undertakings by raising the prices of widgets in the local market. Under the existing SCM Agreement, the neighboring Ruritania is precluded from instituting countervailing duty proceedings, or to submit a complaint to the WTO, against the increased imports from Urbania of low-priced semi-conductors, even if these cause material injury to its domestic semi-conductor industry.

One could also change the facts of the hypothetical, so that instead of inducing the widget sector to subsidize the semi-conductor sector by means of legislation, it is done through bargaining. If, for instance, the Government of Urbania offer the widget sector tax breaks in return for its undertaking to ensure the gradual growth of the semi-conductor sector, the financial contributions received by the latter would still probably remain outside of the scope of Article 1 of the SCM Agreement. The UAWM has not been directed, nor entrusted, to make those payments, and it is unclear whether they are functions that would normally be vested in the government. ${ }^{49}$ It is also questionable whether one could consider the practice followed by this body, as one that in no real sense differs from practices normally followed by governments. It is even questionable whether the tax breaks given to the widget sector may qualify as a subsidy to this sector, considering that these tax breaks may have been offset by the costs of the financial contributions made to the semi-conductor sector. Hence, even though the requirement that there be a "financial contribution" is met, ${ }^{50}$ the "benefit" requirement may not be. ${ }^{51}$ It may also be the case that the widgets aren't exported at all to Ruritania, and therefore cannot be countervailed, and even if they were, the cause of the material injury is the semi-conductors - not the widgets.

These hypotheticals help to illustrate the illogic of the restrictive definition of subsidies in the SCM Agreement, and in particular of the "private body" provision. Since the drafters of the provision clearly had understood that governments could use private bodies in order to channel subsidies through them to selected beneficiaries, they ought to have realized that such use could be made by means more subtle than express directions carried out with governmental attributes. What should count is the fact that there is a governmentally induced subsidy by direct transfer of funds, which makes no commercial sense per se (in the absence of the governmental interference), and which confers a benefit on the recipient in relation to the market. The definition should therefore have been formulated in such a way as to prevent the

\footnotetext{
${ }^{49}$ See Article 1.1(a)(1)(iv) of the SCM Agreement.

${ }^{50}$ Under Article 1.1(a)(1), tax breaks ("government revenue that is otherwise due is foregone or not collected (e.g. fiscal incentives such as tax credits)" are also considered as a "financial contribution".

${ }^{51}$ Ibid., Article 1.1(b).
} 
possibility of evading the provisions of the SCM Agreement simply by transferring the subsidizing function to a private body.

A revised definition of the "private body provision", should be based on a different characterization of such a subsidization, namely: (1) The fact that the financial contribution is "governmentally induced", i.e., that it is made by reason of a governmental decree or direction; (2) The fact that the private body that makes the contribution does not receive any real consideration for its payment, in the form of goods or services; and (3) The fact that the financial contribution is granted on the manufacture of a product by another private firm that sells its product on the market, and not to the payer of the contribution. ${ }^{52}$

It should be stressed in this regard, that the types of subsidies we are discussing here are in any case not prohibited per se. Since they are not contingent upon export performance, nor upon the use of domestic over imported goods, ${ }^{53}$ they could at most be considered under the category of "actionable" subsidies of the SCM Agreement. ${ }^{54}$ This means that they could give rise to a cause of action only if they cause adverse effects to the interest of other countries, such as injury to their domestic industry or other serious prejudice, as defined in the Agreement. ${ }^{55}$ (They would also have to be "specific" in accordance with Article 2 of the Agreement.) ${ }^{56}$ The proposed revision of Article 1 would therefore not affect purely domestic subsidy schemes with no adverse effects on other countries. If, however, the product enjoying the private subsidy is exported to other countries and cause material injury, and if it is "specific", it may give rise to countervailing duty investigations in those countries (or to complaints to theD ispute Settlement Body of the WTO, if that is a more appropriate line of action in view of the circumstances). The status of the recipient under a revised definition would therefore not be any different than if it had received the subsidies directly from the government.

Coming back to the specific issue of the German recycling scheme and the like, I am not claiming that the scheme in itself is unjustified or harmful.

\footnotetext{
${ }^{52}$ This element is partly included in the pre-condition for the imposition of countervailing duties, found in Article VI:3 of the GATT, supra note 18, i.e., that the bounty or subsidy has been "determined to have been granted, directly or indirectly, on the manufacture, production or export of such product in the country of origin...". See also footnote 36 of the SCM Agreement, which defines the term "countervailing duties".

${ }^{53}$ See ibid. Article 3.1.

${ }_{55}^{54}$ See ibid. Part III of the Agreement (Articles 5-7).

${ }^{55}$ Ibid., Articles 5 and 6.

${ }^{56}$ According to Article 8 of the SCM Agreement, subsidies which are not specific within the meaning of Article 2 shall be considered as non-actionable. Article 2 defines specificity as whenever a subsidy is specific to an enterprise or industry or group of enterprises or industries, and sets out several principles by which this should be judged. In Article 2.3 it is provided, that any subsidy falling under the provision of Article 3, which defines "prohibited subsidies", shall be deemed to be specific. Article 3 deals with export subsidies and subsidies contingent upon the use of domestic raw material or components. This means that only the so-called "Actionable Subsidies", dealt with in Part III of the SCM Agreement, i.e., domestic subsidies that cause adverse effects to the interest of other Members, are required to be "specific". It should be mentioned, however, that it is questionable whether the requirement of specificity is still in force, considering the fact that the provisions of Article 8 and 9 were only applied provisionally for a period of five years (Article 31), and no decision to extend this period has been taken, yet.
} 
Waste and garbage that is not recycled clearly entail a social cost that justify the interference of government, sometimes even by subsidies, in order to remedy the market failure. The problem emerges when the waste or the recycled products are exported to other countries and only under circumstances where they cause harm to the recycling industry and environment of those countries. In such circumstances, it would seem that the optimal remedy for the importing country that is suffering the harm is to use countervailing duties to offset the benefit of the subsidy or the injury - regardless of whether the subsidy is paid by the government or by a private body induced to do so by the government. Such a response will not invalidate the subsidized recycling scheme of the exporting country, nor cause it to be repealed, but only remedy some of its harmful side-effects. The harmful exports are usually only a small fraction of the entire production, and to the extent that the countervailing duties will reduce the quantities of those, this is unlikely to cause significant problems to the German recycling plants. There is also the possibility that these exports will find alternative markets where they do not cause any harm.

\section{Harm to the Environment as "Adverse Effect"}

Another notable deficiency in the SCM Agreement that is illustrated by our case, is the fact that the definition of "adverse effects" - a condition for a subsidy to be considered "actionable" - does not include harm to the environment. The relevant provision, namely Article 5 of the SCM Agreement, provides:

No Member should cause, through the use of any subsidy referred to in paragraphs 1 and 2 of Article 1, adverse effects to the interests of other Members, i.e.:

(a) injury to the domestic industry of another Member;

(b) nullification or impairment of benefits accruing directly or indirectly to other Members under GATT 1994 in particular the benefits of concessions bound under Article II of GATT 1994;

(c) serious prejudice to the interest of another Member.

All three of these alternative definitions of "adverse effects" appear to refer only to various harms to the commercial interests of other Members, and not to any other interest. The first refers expressly to injury to the industry of another Member. ${ }^{57}$ The second, refers to the term "nullification or impairment of benefits", that is also found at the basis of GATT's provisions on dispute resolution (Article XXIII). ${ }^{58}$ The GATT 1994 is an agreement on international trade. Hence, the benefits accruing to other Members under it are usually commercial benefits, i.e., benefits to the export or

\footnotetext{
${ }^{57}$ Footnote 11 to this provision leaves no room for doubt, when it provides that the term "injury" is used here in the same sense as it is used in Part V. That means that the very precise provisions of Article 15 of the SCM Agreement, pertaining to the determination of injury, will apply here too. According to this provision, injury relates clearly to negative effect on the domestic producers. ${ }^{58}$ Article XXIII of GATT 1994, supra note 18 ("Nullification or Impairment").
} 
import-substituting activities of their domestic producers. Since GATT 1994 does not include the protection of the environment as one of its objectives, ${ }^{59}$ a Member State has poor chances to be heard in claiming that one of the benefits accruing to it under this agreement is that its environment not be harmed. The particular example quoted in this second alternative, namely "the benefits of concessions bound under Article II of GATT 1994", which refer to tariff concessions, also point to the same conclusion. Finally, the third alternative definition refers to "serious prejudice to the interest of another Member". Literally, this wording could have included prejudice to noncommercial interests. However, footnote 13 to this provision appear to preclude such a reading when it provides that the term "serious prejudice" is used here in the same sense as it is used in paragraph 1 of Article XVI of GATT $1994 .{ }^{60}$ From the negotiation history of this provision we learn that paragraph 1 of Article XVI was drawn from Article 25 of the Havana Charter, ${ }^{61}$ and that its original intention was "prejudice to the trade of a member". ${ }^{2}$ Again, the narrow scope of the legitimate interests covered by the original GATT agreement (as distinct from the WTO Agreement) would also lead to the same conclusion.

This situation - or at least the possibility that such an interpretation will be given to Article 5 - is unsatisfactory and requires amendment. As has been illustrated by the examples discussed in this paper, subsidies of one Member can cause harm not only to the commercial interests of another Member, but also to its environment. Considering that the WTO has declared its commitment to sustainable development, and to the protection and preservation of the environment, ${ }^{63}$ and to the fact that the SCM Agreement itself includes some implicit recognition of the importance of these objectives, ${ }^{64}$ one can see no reason why such harm should not be expressly included in the definition of "adverse effects". Such an amendment would be part of the desired "Greening of the GATT" and could be effected by using the amendment procedure provided for in Article X of the WTO Agreement. ${ }^{65}$

Alternatively, the WTO could use its authority to adopt a binding interpretation of any of the Multilateral Trade Agreements pursuant to Article IX of

\footnotetext{
${ }^{59}$ The objective of "sustainable development, seeking to protect and preserve the environment and to enhance the means of doing so" is included in the $1^{\text {st }}$ preamble to the Marrakesh Agreement Establishing the World Trade Organization, reprinted in The Results of the Uruguay Round, supra note 3, p. 6. However, it is not part of the GATT 1994, as this agreement is defined in Article 1 of the General Agreement on Tariffs and Trade 1994. It consists of the provisions of GATT 1947, and various other amending legal instruments, but not including the WTO Agreement.

${ }^{60}$ See footnote 13 to the SCM Agreement, supra note 15.

${ }^{61}$ The Havana Charter for an International Trade Organization. The negotiation of the Charter took place during 1946-1948, but the Charter never entered into force. Some of its provisions served as the basis for GATT 1947.

${ }^{62}$ See Analytical Index - Guide to GATT Law and Practice $\left(6^{\text {th }}\right.$ ed.) (Geneva: GATT, 1994) 411 and 416 (based on the report of the Preparatory Committee on its discussions in London on the ITO Charter). The various panel reports that have discussed the term "serious prejudice" also related to prejudice to commercial interests of other states (ibid.).

${ }^{63}$ See note 59 above.

${ }^{64}$ See Article 8.2 of the SCM Agreement, supra note 15, which defines assistance to promote adaptation of existing facilities to new environmental requirements as a non-actionable subsidy. ${ }^{65}$ Supra, note 59 According to this provision, such an amendment could be proposed by any Member of the WTO, or by the Council of Trade in Goods, by submitting such proposal to the Ministerial Conference. The decision to amend would have to be taken by the Ministerial Conference, in accordance with the various options provided for in Article X.
} 
the WTO Agreement. ${ }^{66}$ This procedure was used recently in relation to a disputed provision of the TRIPs Agreement. ${ }^{67}$ In our case, it would require a recommendation by the Committee on Subsidies and Countervailing Measures followed by a decision taken by a three-quarters majority of the members within the General Council or the Ministerial Conference, according to which the words "adverse effects to the interests of other Members" in Article 5 of the SCM Agreement would be declared to include harm to such Members' environment.

\section{Can an Importing Country Find Remedy under Article XX of GATT?}

An alternative remedy for the country whose recycling activities have been hampered by imports can be found if the protective measures could be permitted under Article XX of the GATT. This is a "General Exceptions" provision that has been the focus of much of the trade and environment debate and dispute resolution. ${ }^{68}$ When the provision is successfully invoked, it can grant an exemption from any of the GATT/WTO obligations. Thus, a Member State can, for instance, decide to bar the importation of waste for recycling, or of recycled waste, if it considers such imports to harm the collection and recycling of its own waste, and try to invoke one of the Article XX exceptions in order to justify such a decision. Alternatively, it could limit such importation by a quota, or impose some type of import tax on it (such as a countervailing duty). All of these actions are generally prohibited under GATT, unless they can be justified under Article XX. ${ }^{69}$

The discussion of the possibility of invoking one of the GATT Article XX exceptions is relevant not only to the GATT/WTO regime, but also to many other bilateral and regional trade agreements. The reason for this is that many of these

\footnotetext{
${ }^{66}$ According to Article IX:2 of the WTO Agreement, the Ministerial Conference and the General Council shall have the exclusive authority to adopt interpretations of the WTO Agreement itself and of any of the Multilateral Trade Agreements, a term which includes the SCM Agreement. Since this agreement is included in Annex 1, it would require a recommendation by "the Council overseeing the functioning of that Agreement", which is the Committee on Subsidies and Countervailing Measures.

${ }^{67}$ Declaration on the TRIPS Agreement and Public Health, WT/MIN(01)DEC/W/2 of 14.11.01, found on the WTO website: http://www.wto.org/english/thewto_e/min01_e/mindecl_tripts_e.htm

${ }^{68}$ The much celebrated tuna-dolphin controversy centered around this provision. The controversy was the subject of two GATT disputes and panel decisions: United States - Restrictions on Imports of Tuna B.I.S.D. $39^{\text {th }}$ Supp. 155 (1992); and United States - Restrictions on Imports of Tuna 33 I.L.M. 839 (1994), none of which were adopted by the General Council of GATT. The literature on this dispute is vast. See, e.g., Ted McDorman, "The 1991 US-Mexico GATT Panel Report On Tuna and Dolphin: Implications for Trade and Environmental Conflicts" 17 North Carolina J. Int'l L. and Com. Reg. 461 (1991); Steve Charnowitz, "Environmentalism Confronts GATT Rules", 27 J. World Trade 37 (1993); Ernst-Ulrich Petersmann, "International Trade Law and International Environmental Law, 27 J. World Trade 43 (1993); S.T. Spracker \& D. Lundsgaard, "Dolphins and Tuna: Renewed Attention on the Future of Free Trade and Protection of the Environment" 18 Col. J. of Env. L. 385 (1993). Later, the controversy was raised again in the shrimp-turtle case before a WTO panel: United States - Import Prohibition of Certain Shrimp and Shrimp Products, Report of the Panel, WT/DS2/R (1996); Report of the Appellate Body, WT/DS58/AB/R (1998). This report was adopted by the DSB.

${ }^{69}$ Barring imports of any goods from a WTO Member State, or limiting them by an import quota, is contrary to Article XI of GATT, which prohibits the use of any prohibitions or restrictions other than duties, taxes or other charges, on the importation of any product from another Member State. Imposing an import tax on such goods is also prohibited if it exceeds the bound tariff rate included in the tariff schedule of the importing state, unless it is permitted under other provisions of the GATT/WTO regime.
} 
international trade regimes incorporate the Article XX exceptions by express or implicit reference. This is the case, for instance, with the North American Free Trade Agreement (NAFTA) ${ }^{70}$ the Israel-U.S. Free Trade Agreement, ${ }^{71}$ and many other bilateral trade agreements. ${ }^{72}$

In order to qualify for an Article XX exception, the measure in question must not be applied "in a manner which would constitute a means of arbitrary or unjustifiable discrimination between countries where the same conditions prevail, or a disguised restriction on international trade". This provision is commonly referred to as the "chapeau". It also needs to fit into one of the subparagraphs of Article XX. The proper sequence of steps for carrying out an analysis under Article XX, according to the case law of the WTO Appellate Body, ${ }^{73}$ is to first find provisional justification by reason of characterization of the measure under one of the paragraphs (a) to (j), and then to proceed to further appraisal of the same measure under the Article XX chapeau. The Appellate Body has stated that this approach is necessary because whether a measure constitutes "arbitrary discrimination" or "unjustifiable discrimination," or a "disguised restriction on international trade," will depend on which category of measures, under paragraphs (a) to (j), the measure at issue falls under. $^{74}$

The paragraphs that are potentially relevant in our case, as well as in most other cases involving environmental disputes, are paragraphs (b) and (g).

\section{Article $\mathbf{X X}(b)$ : "necessary to protect human, animal or plant life or health"}

Article XX(b) relates to measures that are "necessary to protect human, animal or plant life or health". This provision can be relevant to our case, only if it can be shown that the reduction in collection and recycling of waste in the importing country, as a result of the imports, may harm the life or health of humans, animals or plants. This could be the case, if, as a result of the imports, waste is left or thrown away in the nature where it may harm the health of humans, animals or plants, especially if it is poisonous or otherwise hazardous material. Even in such a case, however, one would have to show that the import measure taken by the importing country is "necessary", in accordance with the interpretation given to this requirement in WTO case-law, meaning that it is the least trade-distorting measure reasonably available to the importing country in order to solve this problem. This issue shall be discussed further below. ${ }^{75}$

\footnotetext{
70 See the North American Free Trade Agreement, 32 I.L.M. 289 and 605 (1993), Article 2101:1, which provides: "GATT Article XX and its interpretative notes, or any equivalent provision of a successor agreement to which all Parties are party, are incorporated into and made part of this Agreement."

${ }^{71}$ Agreement on the Establishment of a Free Trade Area between the Government of Israel and the Government of the United States of America, 24 I.L.M. 653 (1985), Article 7.

${ }^{72}$ See e.g. Free Trade Agreement between the Government of Canada and the Government of the State of Israel, (S.C. 1996, Ch. 33), Article 10.1.

${ }^{73}$ United States - Standards for Reformulated and Conventional Gasoline, WT/DS2/AB/R (1996) [the

"US-Gasoline Case”]; United States - Import Prohibition of Certain Shrimp and Shrimp Products, WT/DS58/AB/R (1998) [the "Shrimps/Turtle Case”].

${ }^{74}$ Ibid., para. 120.

${ }^{75}$ Paragraph 4. See also the cases listed infra in note 101.
} 


\section{Article $\mathrm{XX}(\mathrm{g})$ : "relating to the conservation of exhaustible natural resources"}

A perhaps more promising alternative for the importing state would be to invoke paragraph (g). This provision exempts measures "relating to the conservation of exhaustible natural resources if such measures are made effective in conjunction with restrictions on domestic production or consumption". There are thus three elements that have to be fulfilled: (1) that the measure is concerned with the "conservation of exhaustible natural resources"; (2) that the measure "relat[es]" to the conservation of exhaustible natural resources; and (3) that the measure is "made effective in conjunction with restrictions on domestic production or consumption". ${ }^{76} \mathrm{We}$ shall now proceed to examine whether all of these three elements are fulfilled in our case.

\section{(i) "Concerned with Conservation of Exhaustible Natural Resources"}

The measure in question is the import restriction or import tax on certain reycled materials. This measureis aimed at promoting recycling of waste, such as used paper or used plastic products, found within the territory of the importing country, which in the absence of the measure will not be recycled. Paper products are made of trees and plastic products of petroleum. Both are exhaustible natural resources, and mankind needs to reuse and recycle these products, lest the natural resources from which they are made be exhausted. Thus, the importing country may rightly argue that the measure it has taken is concerned with the conservation of such exhaustible natural resources. Reference could also be made here to the preamble of the WTO Agreement, which explicitly acknowledges "the objective of sustainable development" and the "preserv[ation] and protect[ion] of the environment" ${ }^{77}$ As was proclaimed by the Appellate Body in theShrimps/Turtle Case, this proves that the Signatories to that agreement were "fully aware of the importance and legitimacy of environmental protection as a goal of national and international policy" ${ }^{78}$ Indeed, recycling of waste is considered all over the world as being one important component of the sustainable development objective. ${ }^{79}$ Thus, it would seem that the first element of paragraph $(\mathrm{g})$ has been fulfilled in this case .This conclusion is of course based upon the assumption that the aim of the import measure in question - and therefore its "concern" - is indeed to promote recycling, and not any other (non-environmental) goal.

One could, however, still raise the question of how a WTO Panel would relate to a country that does not have any of the natural resources in question within its territory (trees or petroleum). In such a case, its import measure would actually be concerned with the conservation of exhaustible natural resources that are found outside its own territory and within the territory of other states. This would evoke the controversy raised by the first Tuna/Dolphin Panel, which held that Article XX(g)

\footnotetext{
${ }^{76}$ Ibid. para. 126.

${ }^{77}$ See supra note 59.

${ }^{78}$ Supra note 73para. 128.

${ }^{79}$ See for instance Article 21 of the Implementation Plan adopted at the World Summit on Sustainable Development held in Johannesburg, 2002, available at http://www.unep.org/wssd/ (last visited March 3, 2004).
} 
only permits signatories to take measures in relation to exhaustible natural resources found within their jurisdiction. ${ }^{80}$ While the second Tuna/Dolphin Panel expressly and forcefully rejected this interpretation, ${ }^{81}$ there is still not a final authoritative postWTO ruling on this issue, given that the Appellate Body chose to avoid it in its Shrimps/Turtle decision. ${ }^{82}$ It is however highly unlikely that the jurisdictional limitation read into paragraphs (b) and (g) by the first Tuna/Dolphin Panel will ever be adopted again by any WTO tribunal, considering its feeble legal basis and problematic political implications. ${ }^{83}$

\section{“Relating” to Such Conservation}

Several GATT Panels have held that the term "relating to" should be taken to mean "primarily aimed" at the conservation of natural resources. ${ }^{84}$ In the US-Gasoline Case $^{85}$, the Appellate Body appears to reserve judgment on whether it agrees with this interpretation or not. ${ }^{86}$ In the later Shrimps/Turtle decision, ${ }^{87}$ the Appellate Body does not raise the issue again, but only notes that the interpreter is required to examine the relationship between the measure at stake and the legitimate policy of conserving exhaustible natural resources. One possible type of relationship that has been recognized by the Appellate Body is that of "ends and means". When such relationship was at issue in the US-Gasoline Case the Appellate Body went on to examine the nature of this relationship, and found that it was "substantial". ${ }^{88}$ When later commenting on this case in the Shrimps/Turtle decision, the Appellate Body stated that it had been a "close and genuine relationship of ends and means". ${ }^{89}$ It then went on to use this criterion, finding that the ends and means relationship between the measure at stake and the legitimate policy of conserving an exhaustible, and, in fact, endangered species, was observably a close and real one. ${ }^{90}$ Could this be said on the measure in question here as well?

\footnotetext{
${ }^{80}$ Supra, note 68para. 5.31.

${ }^{81}$ Supra, note 68para. 5.20.

${ }^{82}$ Supra, note 73para. 133: "We do not pass upon the question of whether there is an implied jurisdictional limitation in Article $\mathrm{XX}(\mathrm{g})$, and if so, the nature and extent of that limitation. We note only that in the specific circumstances of the case before us, there is a sufficient nexus between the migratory and endangered marine populations involved and the United States for purposes of Article XX $(\mathrm{g})$." The Appellate Body is alluding to the fact that the sea turtles at issue are all known to occur in waters over which the United States exercises jurisdiction.

${ }^{83}$ There is no real basis in the text of the two provisions for such a limitation. As for the argument that the original intent of the drafters of GATT 1947, as derived from the Travaux Preparatoires, was to allow only conservation of natural resources within each country's jurisdiction, this argument has no real support from the evidence at hand. As was noted by the second Tuna/Dolphin Panel, neither GATT nor 'general international law' prohibits in principle measures related to things or matters located outside a country's own territory.

${ }^{84}$ Canada-Measures Affecting the Exports of Unprocessed Herring and Salmon, GATT BISD (35 ${ }^{\text {th }}$ Supp) 98 (1988); also followed by the second Tuna/Dolphin Panel, supra note 68, para. 5.22.

${ }^{85}$ Supra, note 73

${ }^{86}$ The Appellate Body merely noted that the phrase "primarily aimed at" is not itself treaty language "and was not designed as a simple litmus test for inclusion or exclusion from Article XX $(\mathrm{g})$ ".

Nevertheless, since all the participants in that appeal accepted the propriety and applicability of this interpretation, it saw no need to rule on it, and proceeded to examine whether the measure in question fulfilled this requirement.

${ }^{87}$ Supra, note 73paras.136 -142.

${ }^{88}$ US-Gasoline Case, supra note 73, p. 19.

${ }^{89}$ Shrimps/Turtle Case, supra note 73, para. 136.

${ }^{90}$ Ibid. para. 141.
} 
It would seem that the relationship in our case is less close than those examined by the Appellate Body in both the US-Gasoline Case and Shrimps-Turtle Case. In the former case, the import restriction related to the very product that caused the harm to the exhaustible natural resource (clean air), i.e. the type of gasoline that failed to meet a certain standard of cleanliness. In the latter case, the import restriction related to a product (shrimps) the method of harvesting of which caused harm to the exhaustible natural resource (sea turtles). In our case, the import restriction does not relate to the very product that causes harm to the exhaustible natural resource (trees or petroleum), nor to one whose method of production causes such harm. It relates to a product which, if allowed to be imported into the country (at all, or at a certain low price), will impede the economic viability of domestic recycling, and thus may in effect prevent such recycling. This, in turn, will have a negative effect on the aim of conserving the exhaustible natural resources from which such products are made. If this may be considered by a GATT Panel as a "close and genuine" enough relationship, is hard to foresee. Clearly there is an "ends and means" relationship here. As for the closeness and genuineness of this relationship, they should be examined according to the special circumstances of each case. I would argue that as long as there is a reasonable possibility that a causal connection exists between the means and the ends, the fact that there are more than one links in the causal chain should not make a difference: the measure at stake still "relates" to the conservation of exhaustible resources. Of course, one would have to show that there is some likeliness that the measure will promote such conservation, and that without it there is likely to be less recycling and therefore less conservation. A remote possibility that this will be the case will probably not suffice. However, the Appellate Body has also clarified that the availability of an Article XX(g) defense does not depend on some empirical "effects test". ${ }^{91}$ It has conceded that the problem of determining causation is always a difficult one, and thatin the field of conservation of exhaustible natural resources a substantial period of time, perhaps years, may have to elapse before the effects attributable to implementation of a given measure may be observable. ${ }^{92}$ It is therefore enough to show that there is a reasonable relationship between the means and ends, and that the measure in question was imposed with the goal of conservation in mind. One would also have to show, that the measure in question is not disproportionately wide in its scope and reach in relation to the policy objective of recycling and conservation. ${ }^{93}$ Thus, in our case, if it is reasonable to expect that the importation of recycled materials, in particular if these are sold at prices that are lower than those of the domestic recycled materials, may impede collection and recycling of domestic waste, then it is fair to say that a measure aimed at restricting such imports, or at raising their price by imposing an import duty on them, is closely and genuinely "related" to the conservation of exhaustible natural resources.

\section{(iii) "Made Effective in Conjunction with Restrictions on Domestic Production or Consumption"}

The last part of Article $\mathrm{XX}(\mathrm{g})$, quoted above, is the one most likely to frustrate the possibility of invoking it in the case at hand. The importing country is not putting, in

\footnotetext{
${ }^{91}$ US-Gasoline Case, supra note 73, p. 20.

${ }^{92}$ Ibid.

${ }^{93}$ See Shrimp-Turtle Case, supra note 73, para. 141.
} 
conjunction with the import measures, any "restrictions on domestic production or consumption", as required by the provision. On the contrary; the import restriction is aimed at encouraging and increasing domestic production of the recycled material (and consequently of recycling, as such). In fact, it can be claimed to give preference to recycling of domestic waste over foreign waste, while both are equally important to the conservation of exhaustible natural resources. This part of the provision is therefore likely to present a serious obstacle for a country wishing to invoke it in the circumstances described.

In the U.S. Gasoline Case, the Appellate Body held that this clause constitutes a requirement of even-handedness in the imposition of restrictions, in the name of conservation. ${ }^{94}$ What it says is essentially, that such restrictions must be imposed not just in respect of imported products, but also with respect to domestic products. The rationale behind this requirement is quite evident: if the conservation measures are imposed only on imported products, and not on domestic ones, they are most probably not genuine conservation measures, but rather disguised restrictions on international trade aimed at protecting local producers. But this makes sense only when the imported product itself, or its production process, is the cause of the harm to the exhaustible natural resources. Then, it doesn't matter where the product is produced, whether abroad or in the importing country. In both cases one could expect harm to the exhaustible natural resources, and therefore can demand that the restrictions on the imports "are made effective in conjunction with restriction on domestic production or consumption." In the case at hand, however, the harm to these resources stems not from the products themselves, nor from their production process, but rather from their adverse economic impact on a certain domestic conservation activityThis activity is served best in this case not by restrictions on domestic production, but, quite on the contrary, by encouraging and protecting domestic production (= recycling of domestic waste).

Again, we seem to be faced with a clash between form and substance, between the black letter of the law and its spirit and intent. The lack of restrictions on domestic production or consumption in this case is not a sign of uneven-handedness. On the contrary; the import restriction, in particular if it is in the form of a countervailing duty, is aimed at restoring even-handedness and equality, and to allow the continuation of recycling activity in the importing country just like recycling is taking place in the exporting country. Recycling in the exporting country does not have to come at the expense of recycling in the importing country, and vice versa. However, as long as WTO panels and the Appellate Bodyare obliged to follow the precise "letter of the law" and the plain meaning of the WTO agreements' provisions, as opposed to teleological theories of legal interpretation, ${ }_{95}^{95}$ we are bound to have occasional "mishaps" such as the one described here. ${ }^{96}$

\footnotetext{
${ }^{94}$ US-Gasoline Case, supra note 73, p. 19.

${ }^{95}$ Under a teleological, purposive, interpretative approach, in contrast, one may have reached the conclusion that since the purpose of the provision is to ensure even-handedness and prevent discrimination, and since in this case even-handedness is ensured, there is no reason to block a member state's invocation of Article $\mathrm{XX}(\mathrm{g})$. One could also explain that the scope of the provision is limited to cases where the imported product itself, or its production process, is the cause of the harm to the exhaustible natural resources, for reasons explained in the text above. Another and less activist solution could be reached in some cases by giving a lenient interpretation of the requirement of "restrictions on domestic production or consumption", so that several types of domestic governmental measures in relation to recycling could qualify as such "restrictions". One could think of examples such as
} 


\section{The Chapeau of Article XX}

Only if one reaches the conclusion that the import measure in question falls within the terms of Article XX(b) or (g), one needs to address the question of whether that measure also meets the requirements of the chapeau of Article XX. This opening clause of Article XX deals more with the manner in which that measure is applied than with its specific content. ${ }^{97}$ It prohibits such application of a measure at issue (otherwise falling within the scope of Article XX $(\mathrm{g})$ ) as would constitute "arbitrary or unjustifiable discrimination" between countries where the same conditions apply, or a "disguised restriction on international trade".

The import measure in our case is on its face discriminatory, whether in the form of a levy imposed on the imported recycled products, and not on like domestic products, or in the form of an import restriction, while not restricting domestic production similarly. ${ }^{98}$ The question, however, remains if it constitutes an "arbitrary or unjustifiable" discrimination? Clearly, there must be more to the measure than just "discrimination". Otherwise almost no measure that violates Article III ("National Treatment") or Article XI ("Quantitative Restrictions") would be capable of qualifying for an Article XX exception. As has been recognized by the Appellate Body, the provision of the chapeau could not logically refer to the same standards by which a violation of a substantive rule has been determined to have occurred, lest we deprive Article XX of any meaning. ${ }^{99}$ In this case one would argue that the discrimination between imported and domestic goods is not arbitrary or unjustified, but rather based on a relevant distinction: the imported goods is subsidized and therefore lower priced, while the domestic goods is not. Moreover, the conditions that prevail in the two countries are not the same; the exporting country has legislation that mandates recycling and places its costs on the industry, while the importing country has no such legislation, and perhaps no political or bureaucratic means to adopt and enforce it. Thus, the condition, according to the chapeau, for the existence of "unjustified discrimination" is not fulfilled. The measure in question can also not be seen as a "disguised restriction on international trade", since it does not amount to a "concealed or unannounced measure", nor to an "abuse or illegitimate use" of any of the exceptions of Article XX under the guise of a legitimate measure. ${ }^{100}$ Therefore, the importing country would seem to be justified under Article XX when taking one of these measures in order to preserve domestic recycling and conservation of exhaustible natural resources.

\section{The Requirement to Adopt the "Least Trade Restrictive Measure"}

\footnotetext{
regulations on who may engage in recycling, restricting it to firms authorized by the authorities as fulfilling certain environmental standards etc.

${ }^{96}$ For further discussion of the significance of the interpretative approach of WTO bodies, see below, in the concluding paragraph (para. E).

${ }^{97}$ United States-Gasoline Case, supra note 73para. IV.

${ }^{98}$ As was recognized by the Appellate Body in both the United States-Gasoline Case and the Shrimp/Turtle Case, such discrimination can occur not only between different exporting Members, but also between exporting Members and the importing Member concerned (Shrimp/Turtle Case, supra note 73 , para. 150 ).

${ }^{99}$ Ibid.

${ }^{100}$ To use the Appellate Body's interpretation of this condition, see U.S. Gasoline Case, supra note 73, p. 23.
} 
Another likely obstacle on the use of Article $\mathrm{XX}$ is the requirement on the invoking Member to show that the measure taken is the least trade-distorting measure that can be taken in order to achieve the objectives of either paragraph (b) or $(\mathrm{g})$. This requirement is not spelled out expressly in Article XX, but has been read into several of its components. In particular, it has been seen as part of the "necessity" requirement of subparagraph (b), ${ }^{101}$ and to a lesser degree of subparagraph (g). ${ }^{102} \mathrm{It}$ also appears to have been seen as part of the chapeau, in relation to the "arbitrary or unjustifiable discrimination" clause. This view is based upon the implied rationale that if there is an alternative, less discriminatory measure, that could have achieved the same policy objective with equal effectiveness, then the measure adopted cannot be said to be justified, but rather amounts to "unjustified discrimination". 103

Hence, in our case, a WTO panel may ask the imposing government why it did not resort to a less discriminatory and less trade restrictive alternative, such as taking upon itself to collect the waste, in order to prevent the harm to the environment. Alternatively - so the panel may ask - it could have adopted a recycling regime similar to that of the exporting country (hopefully resulting in similar payments to the domestic recycling plants), thus avoiding the need to resort to discriminatory import measures.

This, again, is where the asymmetry of resources between developed and developing countries comes in. The problem of many developing countries is that they lack both the economic resources and the domestic political clout to adopt the type of sophisticated and expensive recycling schemes that have been adopted in Western developed countries during the last few years. Such schemes require, among other things, elaborate collection facilities spread around the whole country and meticulously planned public relations campaigns in order to create consumer awareness of the importance of recycling. In countries where a large part of the population is concerned with how to provide its most basic needs for sustenance, the chances for such a scheme to succeed are quite slim. Does that mean that they are condemned to see their own limited recycling activities collapse before those of developed countries?

\footnotetext{
${ }^{101}$ Thailand - Restrictions on Importation of and Internal Taxes on Cigarettes, BISD $37^{\text {th }}$ Supp. 200 (1990), paras. 77-80; Korea - Definitive Safeguard Measure on Imports of Certain Dairy Products, WT/DS98/AB/R, adopted 12 January 2000, para. 166; Tuna; Shrimp; EC-Measures Affecting Asbestos and Asbestos-Containing Products, WT/DS135/AB/R, adopted 12 March 2001, para. 172].

${ }^{102}$ Canada-Measures Affecting Exports of Unprocessed Herring and Salmon, BISD $35^{\text {th }}$ Supp. (1988) 98; In the Matter of Canada's Landing Requirement for Pacific Coast Salmon and Herring, Final Report of the Panel, 16 October 1989 (this is a Canada-U.S. FTA Panel, which interprets GATT Article $\mathrm{XX}(\mathrm{g})$ ). Both these decisions precede the establishment of the WTO. In later Appellate Body decisions dealing with Article XX $(\mathrm{g})$ the "least trade restrictive measure" requirement was not read into this subparagraph. See in particular the U.S. Gasoline Case, supra note 73, p. 18, which employs only the "substantial relationship" test under this heading.

${ }^{103}$ See, e.g., the U.S. Gasoline Case, supra note 73, p. 23-27, where both the Panel and the Appellate Body, under the heading of the chapeau, engaged in a lengthy discussion of whether the U.S. authorities had a feasible non-discriminatory alternative in order to achieve its policy goal of preserving clean air. Only after rejecting the U.S. claims that this alternative was realistically not open to it because of administrative difficulties, could these tribunals proceed to their conclusion that the U.S. measure constituted "unjustifiable discrimination" and a "disguised restriction on international trade".
} 
A case that amply illustrates how disregard of this asymmetry may lead to unfair and even unfortunate results is the Thai Cigarette Case. ${ }^{104}$ In that case, the United States challenged a ban on imports of cigarettes into Thailand as a violation of Article XI of the GATT. Thailand defended the ban under Article XX(b) as "necessary to protect human health". While no comparable ban existed on domestic Thai cigarettes, the Thai government claimed that American imports were more likely to induce women and young persons to take up smoking, because of sophisticated advertising directed at those groups. Thailand also argued that American cigarettes were somehow more addictive or more likely to be consumed in larger quantities than comparable Thai cigarettes, due to their chemical composition, but was unable to support this allegation by sufficient scientific evidence. The panel pronounced the Thai measure as inconsistent with the GATT, noting that the Thai government could have introduced alternative non-discriminatory measures, such as labeling and disclosure regulations, general ban on cigarette advertisement and higher taxes. In coming to this conclusion, the panel simply ignored the possibility that what seems as a perfectly sensible alternative to a panel member, may be politically or economically unavailable to the government of a developing country. It may involve high regulatory and compliance costs and may be impracticable to implement effectively within an undeveloped public administration system. Indeed, statistical evidence from Thailand suggests that there was a significant increase in the annual per capita consumption of cigarettes in Thailand following the lifting of the import ban as a result of the GATT panel ruling, ${ }^{105}$ undoubtedly with adverse impact on public health. It is of course hard to establish a clear causal link between the rise in cigarette imports and the increase in consumption, but there is at least a good chance that such link exists and that it supports the claim that the alternative measures suggested by the GATT panel were either unavailable to the Thai authorities or ineffective in curbing cigarette consumption.

Hence, WTO panels ought to be very cautious in utilizing the "least tradedistorting measure" requirement, in particular in relation to developing countries. In our case, it would be totally unacceptable to expect the importing country to adopt a specific model of national recycling promotion, especially one that involves high involvement of government resources. Import measures may therefore be the only viable option, and should not be easily dismissed as failing the "least trade-distorting measure" test.

\section{E. Summary and Indecisive Conclusions: Textualism or Teleology?}

This article has discussed the problem of privately subsidized recycling schemes and their potential harm to the environment of developing countries. In its title, we posed the question of whether international trade law has a solution to this problem. The short answer to this question seems to be that it depends on the interpretative approach that will be taken by the international tribunal charged with ruling on this

\footnotetext{
${ }^{104}$ Thailand - Restrictions on Importation of and Internal Taxes on Cigarettes, BISD $37^{\text {th }}$ Supp. 200 (1990).

${ }^{105}$ Between 1991, when the panel decision was adopted, until 1994, there was an increase of $10 \%$ in cigarette consumption, from 989 cigarettes to 1089 in 1994, for persons age 15 and over. See data quoted by Oren Perez, Ecological Sensitivity and Global Legal Pluralism: Rethinking the Trade and Environment Conflict (Hart Publishing, 2003) 98, in note 264.
} 
matter. A strict textual approach is likely to lead to a negative answer, while a more teleological or purposive approach may in fact lead to a solution, by permitting the harmed country to employ protective import measures. This conclusion has been a recurring theme in our legal analysis of the various relevant provisions.

First, we came across it in our discussion of whether privately subsidized recycling schemes amount to a "subsidy", as this term is defined in the SCM Agreement. We raised the possibility of a purposive interpretation of the words "directed or entrusted", in Article 1.1(a)(1)(iv) of the SCM Agreement, so that it could be seen as encompassing any act that is functionally equivalent to a direction or entrustment. This possibility, however, seems to have been already precluded by the ruling of the WTO Exports Restraints panel ${ }^{106}$, which adopted a strict textual approach requiring an "explicit and affirmative action" and not anything functionally equivalent. While this would preclude the possibility that governmentally induced, but privately paid, subsidies to recycling plants could be considered as a "subsidy" under the SCM Agreement, there is still the possibility that the collection and supply for free of raw-material, in the form of recyclable waste, to recycling plants could qualify as such subsidy. This conclusion may even hold under a textual, non-purposive, approach, given that the private body discussed here - or, at least, the industries that have established it - have in fact been directed or commanded to collect and recycle. However, in order to qualify as a "subsidy", the provision of these goods and services to the recycling plant would still have to fulfill two more conditions specified in the provision, namely that this function is one "which would normally be vested in the government", and that "the practice, in no real sense, differs from practices normally followed by governments". In the discussion above, we suggested several alternative meanings that could be given to these conditions. ${ }^{107}$ It was shown that while generally the Exports Restraints panel has followed a strict textual approach, in its reading of the second condition it has added elements that are not included in the provision. It is suggested that a more likely interpretation should lead to the conclusion that at least the second condition is met by the recycling schemes in question. Nevertheless, it remains questionable, considering in particular the Export Restraints Case, whether WTO panels will be willing to extend the "private body" provision of SCM Agreement Article 1 to include payments or services under such schemes.

Based on our normative analysis of the issue, we reach the conclusion that this situation is unsatisfactory and requires amendment. Since the drafters of the provision clearly had understood that governments could use private bodies in order to channel subsidies through them to selected beneficiaries, they ought to have realized that such use could be made by means more subtle than express directions carried out with governmental attributes. What should count is the fact that there is a governmentally induced subsidy by direct transfer of funds, which makes no commercial sense per se (in the absence of the governmental interference), and which confers a benefit on the recipient in relation to the market. The definition should therefore have been formulated in such a way as to prevent the possibility of evading the provisions of the SCM Agreement simply by transferring the subsidizing function to a private body. It is suggested, therefore, that the WTO use either the amendment procedure, provided for in Article X of the WTO Agreement, or the Article IX mechanism in orderto

\footnotetext{
${ }^{106}$ Supra, note 26

${ }^{107}$ See discussion in para. C:1(e) above.
} 
adopt a binding interpretation of the private body provision, in line with the more logical definition suggested.

The textual-purposive rift was encountered again in connection with the question of whether the term "adverse effects" in Article 5 of the SCM Agreement may be read to include harm to the environment. A strict textual reading, based on reference to negotiation history will lead to the conclusion that the answer is no. A more teleological-purposive approach could consider the WTO Agreement's declared commitment to sustainable development and to the protection and preservation of the environment, as well as the fact that the SCM Agreement itself includes some implicit recognition of the importance of these objectives, and reach an affirmative answer. Since it is unlikely that a WTO panel will adopt the latter approach, it is again recommended that WTO members themselves clarify the matter by using either the amendment or the interpretation mechanism.

Finally, we encountered this recurring theme a third time in our discussion of GATT Article XX, the WTO regime's general exception clause, in connection with the last sentence of subparagraph (g), which requires that the conservation measures are made effective in conjunction with restrictions on domestic production or consumption. While this sentence has been declared by the Appellate Body to constitute a requirement of even-handedness, the lack of restrictions on domestic production or consumption in this case is not a sign of uneven-handedness. On the contrary; the import restriction, in particular if it is in the form of a countervailing duty, is aimed at restoring even-handedness and equality, and to allow the continuation of recycling activity in the importing country just like recycling is taking place in the exporting country. Nevertheless, only a very "free" and purposive interpretation of this provision can avert the outcome rendering the Article $\mathrm{XX}(\mathrm{g})$ exception inapplicable to the case at hand. ${ }^{108}$

If we were to judge from the narrow perspective of these three examples alone, the inevitable conclusion would be that the teleological-purposive approach to interpretation is preferable to the textual-formalistic one, since the former leads to normatively superior results. Not only are these results more satisfactory in terms of environmental values, but they also seem to be more in line with the basic rationales and policy objectives of the WTO and its relevant agreements. This of course is not surprising, since the purposive approach is aimed precisely toward that goal: to interpret the provisions of a specific instrument in line with its perceived policy goals. ${ }^{109}$ This approach recognizes the limits of language and the shortcomings of legal formulations (and formulators...), and strives to rise above the language, whenever it is clear that the plain meaning of the text fails to lead to the policy goals of the instrument in question. However, along with its obvious advantages, the purposive approach has also several drawbacks. Unlike the wording of a treaty, which we know was agreed upon by the parties who signed it, its precise object and purpose is something that is much harder to ascertain. As put by a former member of the WTO Appellate Body:

\footnotetext{
${ }^{108}$ See the suggestions made in note 95 above.

${ }^{109}$ See e.g. Aharon Barak, Interpretation in Law, Vol. 1 ("The General Theory"), 374-375; A. Hart \& A. Sacks, The Legal Process: Basic Problems in the Making and Application of Law (1958) 1157.
} 
"...it is risky to ascertain the object and purpose that the parties pursued if the object and purpose was not expressed in the treaty itself. Though agreeing on a certain text, each party may have very different objects and purposes in mind." $" 110$

There is an inherent risk that the interpreter will impose his own subjective perceptions in relation to the objectives and purposes of the treaty and to their implications for the interpretation of one of its provisions. There is also a lesser degree of certainty and predictability as to the precise meaning of each provision.

Article 31.1 of the Vienna Convention on the Law of Treaties, ${ }^{111}$ stnck a certain compromise between these two interpretative approaches when it provided that "A treaty shall be interpreted in good faith in accordance with the ordinary meaning to be given to the terms of the treaty in their context and in the light of its object and purpose". While giving a certain preference to the "ordinary meaning", the Convention still directs interpreters to attach significance to the treaty's context, object and purpose. The Appellate Body has consistently recognized Articles 31 and 32 of the Vienna Convention as the "customary rules of interpretation of public international law", which it is obliged to follow according to Article 3.2 of the DSU. ${ }^{112}$ However, it is quite clear that it has attached a much greater weight to the first component of the formula ("the ordinary meaning"), than to the other three. ${ }^{113}$ The Appellate Body has in fact opted for the more predictable and less activist method of interpretation. It is also quite clear that what has motivated its choice is the quest for legitimacy. ${ }^{114}$ It has largely protected the Appellate Body and the WTO panels from the criticism that their reports have added to or diminished the rights and obligations provided in the covered agreements, which is expressly prohibited under DSU Article 3.2. ${ }^{115}$ It may also be one of the reasons for the success of the WTO dispute settlement system, whereby in less than a decadit has become a functioning legal system with a decision output that is unsurpassed in international dispute settlement. ${ }^{116}$

It is thereforevery possible that cases such as those discussed in this article, may become victims of the Appellate Body's quest for legitimacy, and perhaps it is not too high of a price to pay. Perhaps these are the hard cases that otherwise would

\footnotetext{
${ }^{110}$ Claus-Dieter Ehlermann, "Reflections on the Appellate Body of the WTO”, 6 J. Int'l Econ. L. 695 (2003), at 699. This point was also made expressly by the Appellate Body when reversing the panel decision in the EC-Hormones Case, stressing that the detail of the text itself may reflect a "delicate and carefully negotiated balance ...between these shared, but sometimes competing, interests of promoting international trade and protecting the life and health of human beings". EC-Measures Concerning Meat and Meat Products (Hormones), Report of the Appellate Body, WT/DS26/AB/R.

${ }^{111}$ Supra, note 39

112 Japan - Taxes on Alcoholic Beverages, Report of the Appellate Body; US-Gasoline Case, supra note 73. In DSU, supra note 24, Article 3.2, the Members declare that the dispute settlement system of the WTO serves to "clarify the existing provisions of [the covered] agreements in accordance with customary rules of interpretation of public international law".

${ }^{113}$ See also Ehlermann, supra note 110, at p. 699.

${ }^{114}$ See Robert Howse, "Adjudicative Legitimacy and Treaty Interpretation in International Trade Law: The Early Years of WTO Jurisprudence", in The EU, the WTO and NAFTA: Towards a Common Law of International Trade (J.H.H. Weiler, ed.) (Oxford University Press, 2000) 35, at p. 53.

${ }^{115}$ Ehlermann, supra note 110, at p. 699.

${ }^{116}$ Donald MacRae, Comments on Claus-Dieter Ehlermann's Presentation, supra note 110, at p. 709.
} 
have made bad law. It is with this possibility in mind that I have also suggested the "legislative" alternative of amendment or authorized interpretation by the WTO members themselves. On the other hand, the failure in Cancun has demonstrated that the political sphere of the WTO is in trouble and that its members seem unable to reach any meaningful agreement at the time being. It is often in the wake of such political stalemates that judicial activism is forced to emerge. If this will be the case in the WTO only the future will tell. 